九州大学学術情報リポジトリ

Kyushu University Institutional Repository

\title{
Syntheses and Biological Activities of 3- Fluoropropionic Acid Derivatives and Related Compounds
}

\section{Kuwano, Ei ichi}

Laboratory of Pesticide Chemistry, Faculty of Agriculture, Kyushu University

Yamashita, Toru

Laboratory of Pesticide Chemistry, Faculty of Agriculture, Kyushu University

Ota, Hiromi

Laboratory of Pesticide Chemistry, Faculty of Agriculture, Kyushu University

Eto, Morifusa

Laboratory of Pesticide Chemistry, Faculty of Agriculture, Kyushu University

https://doi.org/10.5109/23874

出版情報：九州大学大学院農学研究院紀要. 32 (3/4)，pp.147-156，1988-03. Kyushu University バージョン：

権利関係: 


\title{
Syntheses and Biological Activities of 3-Fluoropropionic Acid Derivatives and Related Compounds
}

\author{
Eiichi Kuwano, Toru Yamashita, Hiromi Ota \\ and Morifusa Eto \\ Laboratory of Pesticide Chemistry, Faculty of Agriculture, \\ Kyushu University 46-02, Fukuoka 812 \\ (Received September 1, 1987)
}

\begin{abstract}
3-Fluoropropionates, 3-fluoropropyl ethers, fluorinated homomevalonolactone and related compounds were synthesized, and bioassayed on the silkworm, Bombyx mori, and the housefly, Musca domestica. A number of 3-fluoropropionates showed moderate acute toxicity against both B.mori and $M$. domestica, and 3-fluoropropyl ethers at high doses showed insecticidal activity against B.mori. No acute toxicity was found for fluorinated homomevalonolactone, but weak inhibition of pupation, None of the compounds produced clear anti-juvenile hormone activity on $B$. mori.
\end{abstract}

\section{INTRODUCTION}

Juvenile hormones $(\mathrm{JH})$ and ecdysones are the principal hormones regulating molting, metamorphosis, diapause and reproduction in insects (Wigglesworth, 1985). There have been so far discovered five naturally occurring $\mathrm{JHs}$, that is, JH 0 , JH I, JH II, JH III and iso-JH 0 (Scheme 1). These hormones are ethyl-branched (homo-) sesquiterpenoids except for JH III. In the biosynthesis of common sesquiterpenoids such as JH III, mevalonic acid is a precursor, while homomevalonic acid, which is formed from propionyl-CoA and two acetyl-CoA units, has been known to be a precursor of homosesquiterpenoids. Propionate has been established as the source of the ethyl side branches in JH 0, I, II and iso-JH 0 (Schooley et al., 1985). The biosynthesis of these homosesquiterpenoids offers several potentially attractive targets for insect-specific control agents, because the biosynthetic pathway involving<smiles>[R]C(=CCC([R2])C([R3])=CC(=O)OC)CCC1OC1([R])C</smiles>

JH 0: $\mathrm{R}=\mathrm{R},=\mathrm{R}_{3}=\mathrm{C}_{2} \mathrm{H}_{5}, \mathrm{R}_{2}=\mathrm{H}$

JH I: $\mathrm{R}=\mathrm{R},=\mathrm{C}_{2} \mathrm{H}_{5}, \mathrm{R}_{2}=\mathrm{H}, \mathrm{R}_{3}=\mathrm{CH}$,

JH II : R $=\mathrm{C}_{2} \mathrm{H}_{5}, \mathrm{R},=\mathrm{R}_{3}=\mathrm{CH}, . \mathrm{R}_{2}=\mathrm{H}$

JH III : R $=\mathrm{R},=\mathrm{R}_{3}=\mathrm{CH}, \mathrm{R}_{2}=\mathrm{H}$

iso-JH 0: $\mathrm{R}=\mathrm{R}_{1}=\mathrm{C}_{2} \mathrm{H}_{5}, \mathrm{R}_{2}=\mathrm{R}_{3}=\mathrm{CH}$,

Scheme 1. Chemical structures of the juvenile hormones 
homomevalonate is unique to insects.

It is well known that the use of fluorine as an isosteric replacement for a hydrogen atom in an organic molecule can produce compounds which masquerade effectively as ligands or substrates in biological systems (Prestwich, 1986). For example, the anti-JH activity of fluoromevalonolactone (tetrahydro-4-fluoromethyl-4-hydroxy-2 $H$-pyran-2-one, $\mathrm{FMev}$ ) has been due to inhibition of JH biosynthesis at the level of enzymatic phosphorylation of mevalonate and homomevalonate (Quistad et al., 1981). So we synthesized a number of 3-fluoropropionic acid derivatives, fluorinated homomevalonolactone and related compounds, and assayed for acute and delayed effects on the housefly, Musca domestica and the silkworm, Bombyx mori.

\section{EXPERIMENTAL}

\section{Syntheses}

Melting points were uncorrected. NMR spectra were measured with a JEOL FX -100 spectrometer with tetramethylsilane as an internal standard.

3-Fluoropropanol (1)

A mixture of 3-chloropropanol (76 g, $0.8 \mathrm{~mol})$ and potassium fluoride (70 g, $1.7 \mathrm{~mol}$ ) in ethyleneglycol $(100 \mathrm{ml})$ was heated at $150-180^{\circ} \mathrm{C}$ with stirring and subsequently the distillate at $100-180^{\circ} \mathrm{C}$ was collected in the course of $6 \mathrm{hr}$. Redistillation at $120^{\circ} \mathrm{C}$ gave $44 \mathrm{~g}(70 \%)$ of 3-fluoropropanol. NMR $\left(\mathrm{CDCl}_{3}\right) \delta: 1.06-2.25(2 \mathrm{H}, \mathrm{m}), 2.33(1 \mathrm{H}, \mathrm{s}), 3.75$ $(2 \mathrm{H}, \mathrm{t}, \mathrm{J}=6 \mathrm{~Hz}), 4.20-4.90(2 \mathrm{H}, \mathrm{dt}, \mathrm{Ja}=48 \mathrm{~Hz}, \mathrm{Jb}=6 \mathrm{~Hz})$.

3-Fluoropropionic acid (2)

To a solution of potassium bichromate $(143 \mathrm{~g}, 0.49 \mathrm{~mol})$ in water $(500 \mathrm{ml})$, Concentrated sulfuric acid $(155 \mathrm{ml})$ was added with stirring. After cooling a solution of 3 -fluoropropanol $(47 \mathrm{~g}, 0.6 \mathrm{~mol})$ in water $(200 \mathrm{ml})$ was added dropwise to the mixture over a period of $4 \mathrm{hr}$. The reaction mixture which turned from deep red to dark green was stirred overnight at room temperature. The product was extracted with ethyl acetate $(250 \mathrm{mlX} 5)$ and the combined organic layer was dried over $\mathrm{Na}_{2} \mathrm{SO}_{4}$, concentrated under reduced pressure. The residue was distilled to give $32 \mathrm{~g}(58 \%)$ of 3 fluoropropionic acid as a colorless oil, bp $120^{\circ} \mathrm{C}(0.4 \mathrm{~mm})$. NMR $\left(\mathrm{CDCl}_{3}\right) \delta: 2.30-3.40$ $(2 \mathrm{H}, \mathrm{dt}, \mathrm{Ja}=25 \mathrm{~Hz}, \mathrm{Jb}=6 \mathrm{~Hz}), 4.3-5.06(2 \mathrm{H}, \mathrm{dt}, \mathrm{Ja}=48 \mathrm{~Hz}, \mathrm{Jb}=6 \mathrm{~Hz}), 11.10(1 \mathrm{H}, \mathrm{s})$. General method for the preparation of esters of 3-fluoropropionic acid. (compounds 3 -15 , Table 1)

(Method A)

To a mixture of 3-fluoropropionic acid and an alcohol (large excess) was added a few drops of conc. sulfuric acid and the mixture was allowed to stand for 3-5 days. To the reaction mixture, ether was added and the ether layer was washed with 5\% $\mathrm{NaHCO}_{3}$, dried over $\mathrm{Na}_{2} \mathrm{SO}_{4}$. After removal of the solvent, the residue was purified by distillation or column chromatography on silica gel by elution with solvent mixtures (hexane-ethyl acetate) of increasing polarity.

(Method B)

A mixture of 3-fluoropropionic acid and an alcohol (excess) in benzene containing a catalytic amount of $p$-toluenesulfonic acid was refluxed for $3 \mathrm{hr}$ removing water by using a water separator. After cooling, the solvent was removed under reduced pressure and the residue was purified by column chromatography on silica gel, distilla- 
Table 1. Structures, yields and physical properties of 3-fluoropropionates.

\begin{tabular}{|c|c|c|c|c|c|}
\hline No & $\underset{\mathrm{R}}{\mathrm{FCH}_{2} \mathrm{CH}_{2} \mathrm{COOR}}$ & Method & $\begin{array}{l}\text { Yield } \\
(\%)\end{array}$ & $\begin{array}{l}\text { Bp or } \\
\mathrm{Mp}^{*}\end{array}$ & $\begin{array}{c}{ }^{1} \mathrm{H} \mathrm{NMR} \\
\left(\mathrm{CDCI}_{3}\right) \delta \mathrm{ppm}\end{array}$ \\
\hline 3 & $\mathrm{C}_{2} \mathrm{H}_{5}$ & A & 17 & 96 & $\begin{array}{l}1.28(3 \mathrm{H}, \mathrm{t}, \mathrm{J}=6 \mathrm{~Hz}), 2.72(2 \mathrm{H}, \mathrm{dt}, \mathrm{Ja}=26 \\
\mathrm{Hz}, \mathrm{Jb}=6 \mathrm{~Hz}), 4.16(2 \mathrm{H}, \mathrm{q}, \mathrm{J}=6 \mathrm{~Hz}), 4.70 \\
(2 \mathrm{H}, \mathrm{dt}, \mathrm{Ja}=48 \mathrm{~Hz}, \mathrm{Jb}=6 \mathrm{~Hz})\end{array}$ \\
\hline 4 & $\mathrm{CH}_{2} \mathrm{CH}_{2} \mathrm{~F}$ & A & 17 & $\begin{array}{c}67 \\
(31 \mathrm{~mm})\end{array}$ & $\begin{array}{l}1.6-2.3(2 \mathrm{H}, \mathrm{m}), 2.70(2 \mathrm{H}, \mathrm{dt}, \mathrm{Ja}=26 \mathrm{~Hz} \\
\mathrm{Jb}=6 \mathrm{~Hz}), 4.14(2 \mathrm{H}, \mathrm{t}, 6 \mathrm{~Hz}), 4.50(2 \mathrm{H}, \mathrm{dt} \\
\mathrm{Ja}=48 \mathrm{~Hz}, \mathrm{Jb}=6 \mathrm{~Hz}), 4.66(2 \mathrm{H}, \mathrm{dt}, \mathrm{Ja}=48 \\
\mathrm{Hz}, \mathrm{Jb}=6 \mathrm{~Hz})\end{array}$ \\
\hline 5 & $n-\mathrm{C}_{3} \mathrm{H}_{7}$ & B & 78 & 147 & $\begin{array}{l}0.94(3 \mathrm{H}, \mathrm{t}, \mathrm{J}=6 \mathrm{~Hz}), 1.42-2.0(2 \mathrm{H}, \mathrm{m}), 2.72 \\
(2 \mathrm{H}, \mathrm{dt}, \mathrm{Ja}=24 \mathrm{~Hz}, \mathrm{Jb}=6 \mathrm{~Hz}), 4.08(2 \mathrm{H}, \mathrm{t} \\
\mathrm{J}=6 \mathrm{~Hz}), 4.70(2 \mathrm{H}, \mathrm{dt}, \mathrm{Ja}=46 \mathrm{~Hz}, \mathrm{Jb}=6 \mathrm{~Hz})\end{array}$ \\
\hline 6 & $n-\mathrm{C}_{5} \mathrm{H}_{11}$ & B & 93 & - & $\begin{array}{l}0.94(3 \mathrm{H}, \mathrm{t}, \mathrm{J}=6 \mathrm{~Hz}), 1.1-2.0(6 \mathrm{H}, \mathrm{m}), 2.92 \\
(2 \mathrm{H}, \mathrm{dt}, \mathrm{Ja}=26 \mathrm{~Hz}, \mathrm{Jb}=6 \mathrm{~Hz}), 4.48(2 \mathrm{H}, \mathrm{t} \\
\mathrm{J}=6 \mathrm{~Hz}), 5.10(2 \mathrm{H}, \mathrm{dt}, \mathrm{Ja}=48 \mathrm{~Hz}, \mathrm{Jb}=6 \mathrm{~Hz})\end{array}$ \\
\hline 7 & $n-\mathrm{C}_{8} \mathrm{H}_{17}$ & $\mathrm{C}$ & 17 & - & $\begin{array}{l}0.92(3 \mathrm{H}, \text { deformed t), } 1.1-2.2(12 \mathrm{H}, \mathrm{m}), 2.82 \\
(2 \mathrm{H}, \mathrm{dt}, \mathrm{Ja}=24 \mathrm{~Hz}, \mathrm{Jb}=6 \mathrm{~Hz}), 4.50(2 \mathrm{H}, \mathrm{t} \\
\mathrm{J}=6 \mathrm{~Hz}), 4.90(2 \mathrm{H}, \mathrm{dt}, \mathrm{Ja}=48 \mathrm{~Hz}, \mathrm{Jb}=6 \mathrm{~Hz})\end{array}$ \\
\hline 8 & $n-\mathrm{C}_{10} \mathrm{H}_{21}$ & $\mathrm{C}$ & 22 & - & $\begin{array}{l}0.92(3 \mathrm{H}, \text { deformed t }), 1.1-2.2(16 \mathrm{H}, \mathrm{m}), 2.82 \\
(2 \mathrm{H}, \mathrm{dt}, \mathrm{Ja}=24 \mathrm{~Hz}, \mathrm{Jb}=6 \mathrm{~Hz}), 4.50(2 \mathrm{H}, \mathrm{t}, \\
\mathrm{J}=6 \mathrm{~Hz}), 4.90(2 \mathrm{H}, \mathrm{dt}, \mathrm{Ja}=48 \mathrm{~Hz}, \mathrm{Jb}=6 \mathrm{~Hz})\end{array}$ \\
\hline 9 & $n-\mathrm{C}_{12} \mathrm{H}_{25}$ & B & 86 & - & $\begin{array}{l}0.92(3 \mathrm{H}, \text { deformed } \mathrm{t}), 1.1-2.0(20 \mathrm{H}, \mathrm{m}), 2.84 \\
(2 \mathrm{H}, \mathrm{dt}, \mathrm{Ja}=24 \mathrm{~Hz}, \mathrm{Jb}=6 \mathrm{~Hz}), 4.34(2 \mathrm{H}, \mathrm{t}, \\
\mathrm{J}=6 \mathrm{~Hz}), 4.96(2 \mathrm{H}, \mathrm{dt}, \mathrm{Ja}=48 \mathrm{~Hz}, \mathrm{Jb}=6 \mathrm{~Hz})\end{array}$ \\
\hline 10 & Oleyl & A & 74 & - & $\begin{array}{l}0.90(3 \mathrm{H}, \text { deformed t), } 1.0-1.6(26 \mathrm{H}, \mathrm{m}), 1.8- \\
2.14(1 \mathrm{H}, \mathrm{m}), 2.72(2 \mathrm{H}, \mathrm{dt}, \mathrm{Ja}=24 \mathrm{~Hz}, \mathrm{Jb}=6 \\
\mathrm{Hz}), 4.14(2 \mathrm{H}, \mathrm{t}, \mathrm{J}=6 \mathrm{~Hz}), 4.72(2 \mathrm{H}, \mathrm{dt}, \mathrm{Ja}= \\
48 \mathrm{~Hz}, \mathrm{Jb}=6 \mathrm{~Hz}), 5.1-5.5(2 \mathrm{H}, \mathrm{m})\end{array}$ \\
\hline 11 & Geranyl & $\mathrm{C}$ & 7 & - & $\begin{array}{l}1.70(3 \mathrm{H}, \mathrm{s}), 1.80(6 \mathrm{H}, \mathrm{s}), 2.0-2.5(4 \mathrm{H}, \mathrm{m}), 2 . \\
86(2 \mathrm{H}, \mathrm{dt}, \mathrm{Ja}=24 \mathrm{~Hz}, \mathrm{Jb}=6 \mathrm{~Hz}), 4.90(2 \mathrm{H}, \\
\mathrm{d}, \mathrm{J}=8 \mathrm{~Hz}), 4.98(2 \mathrm{H}, \mathrm{dt}, \mathrm{Ja}=48 \mathrm{~Hz}, \mathrm{Jb}=6 \\
\mathrm{Hz}), 5.2-5.8(2 \mathrm{H}, \mathrm{m})\end{array}$ \\
\hline 12 & Benzyl & A & 11 & - & $\begin{array}{l}2.74(2 \mathrm{H}, \mathrm{dt}, \mathrm{Ja}=24 \mathrm{~Hz}, \mathrm{Jb}=6 \mathrm{~Hz}), 4.68(2 \mathrm{H} \\
\mathrm{dt}, \mathrm{Ja}=46 \mathrm{~Hz}, \mathrm{Jb}=6 \mathrm{~Hz}), 5.12(2 \mathrm{H}, \mathrm{s}), 7.2-7 . \\
5(5 \mathrm{H}, \mathrm{m})\end{array}$ \\
\hline 13 & Piperonyl & $\mathrm{C}$ & 39 & - & $\begin{array}{l}2.86(2 \mathrm{H}, \mathrm{dt}, \mathrm{Ja}=24 \mathrm{~Hz}, \mathrm{Jb}=6 \mathrm{~Hz}), 4.90(2 \mathrm{H}, \\
\mathrm{dt}, \mathrm{Ja}=48 \mathrm{~Hz}, \mathrm{Jb}=6 \mathrm{~Hz}), 5.26(2 \mathrm{H}, \mathrm{s}), 6.18 \\
(2 \mathrm{H}, \mathrm{s}), 6.6-7.3(3 \mathrm{H}, \mathrm{m})\end{array}$ \\
\hline 14 & $\begin{array}{l}\text { m-Phenoxy } \\
\text { benzyl }\end{array}$ & B & 55 & - & $\begin{array}{l}2.84(2 \mathrm{H}, \mathrm{dt}, \mathrm{Ja}=26 \mathrm{~Hz}, \mathrm{Jb}=6 \mathrm{~Hz}), 4.92(2 \mathrm{H}, \\
\mathrm{dt}, \mathrm{Ja}=48 \mathrm{~Hz}, \mathrm{Jb}=6 \mathrm{~Hz}), 5.40(2 \mathrm{H}, \mathrm{s}), 7.1-8 . \\
0(9 \mathrm{H}, \mathrm{m})\end{array}$ \\
\hline 15 & Cholesteryl & B & 84 & $94^{\prime}$ & $\begin{array}{l}0.68(3 \mathrm{H}, \mathrm{s}), 0.7-2.2(41 \mathrm{H}, \mathrm{m}), 2.68(2 \mathrm{H}, \mathrm{dt}, \\
\mathrm{Ja}=24 \mathrm{~Hz}, \mathrm{Jb}=6 \mathrm{~Hz}), 4.70(2 \mathrm{H}, \mathrm{dt}, \mathrm{Ja}=48 \\
\mathrm{Hz}, \mathrm{Jb}=6 \mathrm{~Hz}), 5.2-5.4(1 \mathrm{H}, \mathrm{m})\end{array}$ \\
\hline
\end{tabular}


tion, or recrystallization.

(Method C)

A catalytic amount of 4-dimethylaminopyridine was added to the mixture of 3-fluoropropionic acid, an alcohol (large excess) and N, N'-dicyclohexylcarbodiimide (1.1 eq.) in methylene chloride at $0^{\circ} \mathrm{C}$, and the mixture was stirred for $15 \mathrm{~min}$ at same temperature. After stirring overnight at room temperature, the precipitates were filtered off. The filtrate was dried over $\mathrm{Na}_{2} \mathrm{SO}_{4}$, concentrated, and the residue was purified by column chromatography on silica gel.

General procedure for the preparation of 3-fluoropropyl ethers.

A solution of 3 -fluoropropanol (1, leq.) in dry tetrahydrofuran was added to the emulsion of sodium hydride ( 1 eq.) in tetrahydrofuran, and the mixture was stirred for $15 \mathrm{~min}$. To the resulting solution, catalytic amount of tetra-n-butylammonium iodide was added followed by addition of geranyl chloride or benzyl chloride (1 eq.) solution in tetrahydrofuran, and the mixture was stirred at room temperature overnight. After removing the solvent, the residue was extracted with ether and the ether layer was concentrated. The crude product was purified with column chromatography on silica gel.

Benzyl 3-fluoropropyl ether (16). Yield 59\%. NMR (CDCl, $) \delta: 1.70-2.25(2 \mathrm{H}, \mathrm{m}), 3$. $58(2 \mathrm{H}, \mathrm{t}, \mathrm{J}=6 \mathrm{~Hz}), 4.16-4.86(2 \mathrm{H}, \mathrm{tt}, \mathrm{Ja}=48 \mathrm{~Hz}, \mathrm{Jb}=6 \mathrm{~Hz}), 4.48(2 \mathrm{H}, \mathrm{s}), 7.29(5 \mathrm{H}, \mathrm{m})$.

Geranyl 3-fluoropropyl ether (17). Yield 38\%. NMR $(\mathrm{CDCl},) \delta: 1.59(3 \mathrm{H}, \mathrm{s}), 1.67$ $(6 \mathrm{H}, \mathrm{s}), 1.70-2.30(7 \mathrm{H}, \mathrm{m}), 3.52(2 \mathrm{H}, \mathrm{t} . \mathrm{J}=6 \mathrm{~Hz}), 3.95(2 \mathrm{H}, \mathrm{d}, \mathrm{J}=6 \mathrm{~Hz}), 4.15-4.85(2 \mathrm{H}, \mathrm{tt}$, $\mathrm{Ja}=48 \mathrm{~Hz}, \mathrm{Jb}=6 \mathrm{~Hz}), 5.05(1 \mathrm{H}$, broad $\mathrm{s}), 5.30(1 \mathrm{H}, \mathrm{t}, \mathrm{J}=6 \mathrm{~Hz})$.

(E)-6,7-epoxy-3,7-dimethyl-1-(3-fuoropropyloxy)-2-octene (18) and 2, 3, 6, 7-diepoxy-3, 7-dimethyl-1-(3-fuoropropyloxy)-octane (19)

A solution of m-chloroperbenzoic acid (1.2 eq.) in methylene chloride was added to a solution of a 3-fluoropropyl geranyl ether $\left(1^{\prime} 7,1\right.$ eq.) in methylene chloride at $0^{\circ} \mathrm{C}$ with stirring and the mixture was stirred overnight at $5^{\circ} \mathrm{C}$. To the resulting mixture, $10 \%$ $\mathrm{Na}_{2} \mathrm{SO}_{3}$ was added, and the methylene chloride solution was separated and washed with $5 \% \mathrm{NaHCO}_{3}$, dried over $\mathrm{Na}_{2} \mathrm{SO}_{4}$. After removing the solvent, the residue was purified with column chromatography on silica gel eluted with hexane-ether $(5: 1)$ and $(3: 1)$.

Monoepoxy compound $\mathbf{1 8}$ was obtained from the hexane-ether $(5: 1)$ eluate by concentrating of the eluate under reduced pressure, yield 42\%. NMR (CDCl,) $\delta: 1.27$ $(3 \mathrm{H}, \mathrm{s}), 1.30(3 \mathrm{H}, \mathrm{s}), 1.45-2.33(12 \mathrm{H}, \mathrm{m}), 2.70(1 \mathrm{H}, \mathrm{t}, \mathrm{J}=6 \mathrm{~Hz}), 3.52(2 \mathrm{H}, \mathrm{t}, \mathrm{J}=6 \mathrm{~Hz}), 3.97$ $(2 \mathrm{H}, \mathrm{d}, 6 \mathrm{~Hz}), 4.13-4,82(2 \mathrm{H}, \mathrm{tt}, \mathrm{Ja}=48 \mathrm{~Hz}, \mathrm{Jb}=6 \mathrm{~Hz}), 5.35(1 \mathrm{H}, \mathrm{t}, \mathrm{J}=6 \mathrm{~Hz})$.

Diepoxy compound 19 was eluted after 18 with hexane-ether $(3: 1)$. Yield $25 \%$. NMR (CDCl, ) $\delta: 1.28(3 \mathrm{H}, \mathrm{s}), 1.30(3 \mathrm{H}, \mathrm{s}), 1.32(3 \mathrm{H}, \mathrm{s}), 1.5-2.24(6 \mathrm{H}, \mathrm{m}), 2.70(1 \mathrm{H}$, deformed t), $2.96(1 \mathrm{H}, \mathrm{t}, \mathrm{J}=6 \mathrm{~Hz}), 3.3-3.8(4 \mathrm{H}, \mathrm{m}), 4.54(2 \mathrm{H}, \mathrm{dt}, \mathrm{Ja}=48 \mathrm{~Hz}, \mathrm{Jb}=6 \mathrm{~Hz})$. 4-(2-Chloroethyl)-4-hydroxy-1,6-heptadiene (20).

A solution of ethyl 3-chloropropionate $(20.0 \mathrm{~g}, 147 \mathrm{mmol})$ in ether $(100 \mathrm{ml})$ was added dropwise to a solution of allylmagnesium bromide $(440 \mathrm{mmol})$ in ether over a period of $3 \mathrm{hr}$. After stirring overnight, the mixture was quenched with $1 \mathrm{~N} \mathrm{HCl}$ solution and the product was extracted with ether. The ether layer was dried over $\mathrm{Na}_{2}$ $\mathrm{SO}$, and concentrated under reduced pressure. The residue was distilled affording 8 . $2 \mathrm{~g}(32 \%)$ or 19 , bp $112^{\circ} \mathrm{C}(22 \mathrm{~mm})$. NMR $(\mathrm{CDCl},) \delta: 1.75(1 \mathrm{H}, \mathrm{s}), 1.96(2 \mathrm{H}, \mathrm{m}), 2.24(4 \mathrm{H}$, d, J $=8 \mathrm{~Hz}), 3.64(2 \mathrm{H}, \mathrm{m})$, 5.92-6.04 $(6 \mathrm{H}, \mathrm{m})$. 


\section{4-(2-Fluoroethyl)-4-hydroxy-1,6-heptadiene (21)}

A mixture of hydroxydiene $20(7.1 \mathrm{~g}, 40.7 \mathrm{mmol})$, potassium fluoride $(10.0 \mathrm{~g}, 172.4$ mmol) and ethyleneglycol $(15 \mathrm{ml})$ was heated at $160^{\circ} \mathrm{C}$ for $3 \mathrm{hr}$. After cooling the product was extracted with ether $(50 \mathrm{ml} \times 7)$ and the combined ether solution was dried over $\mathrm{Na}_{2} \mathrm{SO}_{4}$ and concentrated under reduced pressure. The residue was distilled affording $3.8 \mathrm{~g}(58 \%)$ of fluorinated hydroxydiene 21 , bp $94^{\circ} \mathrm{C}(33 \mathrm{~mm}) . \mathrm{NMR}(\mathrm{CDCl},) \delta$ : $1.80(1 \mathrm{H}$, broad s$), 1.68-2.08(2 \mathrm{H}, \mathrm{tt}, \mathrm{Ja}=25 \mathrm{~Hz}, \mathrm{Jb}=6 \mathrm{~Hz}), 2.26(4 \mathrm{H}, \mathrm{d}), 4.32-4.92(2 \mathrm{H}, \mathrm{tt}$, $\mathrm{Ja}=48 \mathrm{~Hz}, \mathrm{Jb}=6 \mathrm{~Hz}), 4.92-6.04(6 \mathrm{H}, \mathrm{m})$.

3-(2-Fluoroethyl)-1, 3, 5-trihydroxypentane (22)

A solution of compound $21(3.2 \mathrm{~g}, 20.3 \mathrm{mmol})$ in methanol $(150 \mathrm{ml})$ was cooled to $-78^{\circ} \mathrm{C}$ in a methanol-dry ice bath and ozone was passed through until the solution turned pale blue (about $3 \mathrm{hr}$ ). After additional $15 \mathrm{~min}$, a solution of sodium borohydride $(19 \mathrm{~g}, 500 \mathrm{mmole})$ in $50 \%$ ethanol $(100 \mathrm{ml})$ cooled in an ice bath was added dropwise to the ozonide solution at $-55^{\circ} \mathrm{C}$. The mixture was allowed to stand at room temperature for $30 \mathrm{~min}$ and heated at $50^{\circ} \mathrm{C}$ for $1 \mathrm{hr}$. After cooling, the solution was acidified with $1 \mathrm{~N} \mathrm{HCl}$ solution, and neutralized with $5 \% \mathrm{NaHCO}_{3}$ solution. After removal of the solvent under reduced pressure, the product was extracted with ethylacetate $(100 \mathrm{ml} \times$ 4). The combined organic layer was dried over $\mathrm{Na}_{2} \mathrm{SO}_{4}$ and concentrated to give 2.43 $\mathrm{g}$ of residue. Purification with silica gel column chromatography afforded $1.3 \mathrm{~g}(40 \%)$ of triol 22. NMR $(\mathrm{CDCl},) \delta: 1.60-2.20(7 \mathrm{H}, \mathrm{m}), 3.00(2 \mathrm{H}$, broad s $), 3.85(4 \mathrm{H}, \mathrm{t}, \mathrm{J}=6 \mathrm{~Hz})$, $4.20-4.90(2 \mathrm{H}, \mathrm{tt}, \mathrm{Ja}=48 \mathrm{~Hz}, \mathrm{Jb}=6 \mathrm{~Hz})$.

Fluorohomomevalonolactone (23)

A mixture of triol $22(650 \mathrm{mg}, 3.9 \mathrm{mmol})$ and freshly prepared silver carbonate on cerite $(30.5 \mathrm{~g}, 53.5 \mathrm{mmol}$ active compound) in dry benzene $(150 \mathrm{ml})$ was refluxed for 20 hr. The mixture was filtered and the filtrate was concentrated to give $510 \mathrm{mg}$ of oil. Distillation under reduced pressure $(0.24 \mathrm{~mm})$ using microdistillation oven (Buchi, GKR $-50)$ at $230-280^{\circ} \mathrm{C}$ gave $360 \mathrm{mg}(50 \%)$ of compound 23 . NMR $(\mathrm{CDCl},) \delta: 1.70-2.20(4 \mathrm{H}$, m), 2.30-2.85 (2H, m), $3.42(1 \mathrm{H}, \mathrm{s}), 4.18-5.00(4 \mathrm{H}, \mathrm{m})$.

\section{Bioassays}

1. Housefly (Musca domestica, WHO's standard susceptible strain)

The larvae were reared on a mixture of commercial housefly feed and rat feed (Oriental Yeast Co., Ltd.) at a 6: 1 ratio and the adults with sugar, skin milk and water. In the larval test, 25 larvae (2-day after hatch) were placed in a beaker to which was added the larval medium and the test compounds at 1000 or $5000 \mathrm{ppm}$ concentration. The compounds were mixed as aqueous solutions with diet and 3-fluoropropionic acid and propionic acid were used after neutralization with $\mathrm{NaHCO}_{3}$. The percentages pupating and subsequently emerging as adults were recorded.

Three to five-day old female adults were treated topically by using acetone solutions. Mortalities were recorded after $24 \mathrm{hr}$.

\section{Silkworm (Bombyx mori, Gunpo X Shugyoku)}

Larvae were reared on artificial diets, Silkmate1S and 2M (Nippon Nosan Kogyo Co., Ltd.) for the 1 st instar and from the 2 nd to 5 th instar larvae, respectively, under a $12 \mathrm{hr}$ light and $12 \mathrm{hr}$ dark photoperiod at $26 \pm 2^{\circ} \mathrm{C}$.

For the topical assay, newly molted 3rd instar larvae were topically treated on the dorsal surface with acetone dilutions of test compounds (single application). After 
treatment of newly molted 3rd instar larvae, the larvae were treated with the test solution at 24-hour intervals during the 3rd instar stage (daily application).

For the feeding assay, test compounds were mixed with artificial diet as acetone solutions or powders. The diet was provided successively to 2 nd instar larvae within $24 \mathrm{hr}$ after ecdysis through 2 nd instar stage.

\section{RESULTS AND DISCUSSION}

\section{Syntheses}

3-Fluoropropanol (1) was prepared by the reaction of 3-chloropropanol with potassium fluoride in ethyleneglycol according to a method described by Pattison et al. (1956). The NMR spectrum for 1 exhibited characteristic proton-fluorine coupling constants $\left(\mathrm{J}_{\mathrm{H}-\mathrm{F}}=48 \mathrm{~Hz}, \mathrm{~J}_{\mathrm{CH}-\mathrm{F}}=26 \mathrm{~Hz}\right)$. The oxidation of 1 with potassium bichromate and sulfuric acid gave 3-fluoropropionic acid (2) in 58\% yield (Scheme 2).

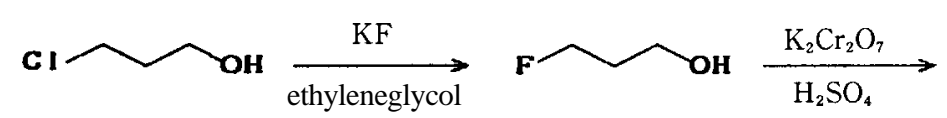

1<smiles>O=C(O)CCF</smiles>

2

Scheme 2. Synthesis of 3-fluoropropionic acid

The esters of 3-fluoropropionic acid were prepared by three different procedures, Methods A, B and C, as shown in Scheme 3. Methods A and B were standard acid-catalyzed esterifications, whereas in Method C dicyclohexylcarbodiimide (DCC) and 4-dimethylaminopyridine (DMAP) were used. Table 1 shows yields and some physicochemical properties of the esters. The NMR spectra for the esters were in agreement with the assigned structures and showed the characteristic proton-fluorine coupling constants.

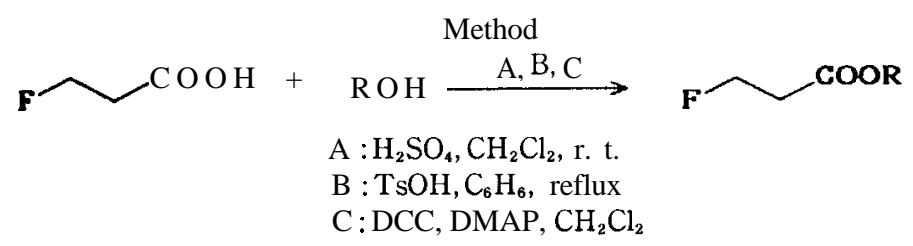

Scheme 3. Synthesis of 3-fluoropropionates

3-Fluoropropyl ethers were synthesized by the reaction of 3-fluoropropanol (1) with alkyl halides in the presence of sodium hydride and tetra-n-butyl ammonium iodide. The epoxidation of 3-fluoropropyl geranyl ether 17 with m-chloroperbenzoic acid afforded monoepoxy ether 18 (42\%) and diepoxy ether 19 (25\%) which were seperated by column chromatography on silica gel (Scheme 4).

The preparation of fluorinated homomevalonolactone 23 was carried out as shown in Scheme 5. The synthesis of hydroxy diene 20 was accomplished by the Grignard reaction between ethyl 3-chloropropionate and ally1 magnesium bromide. Compound 


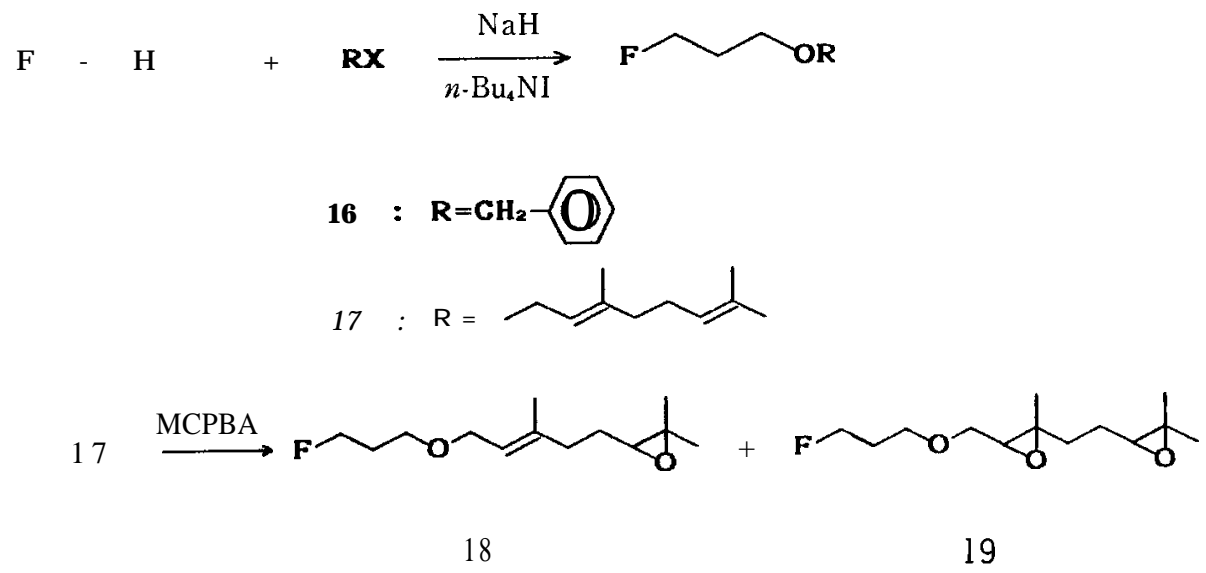

Scheme 4. Synthesis of 3-fluoropropyl ethers<smiles>C=CCC(CC)C(C)CBr</smiles><smiles>C=CCC(O)(CC=C)CCF</smiles>

21<smiles>OCCC(O)(CCO)CCF</smiles>

22<smiles>CC(C)(C)OC1CCCCC1(O)CCF</smiles>

23

Scheme 5. Synthesis of fluorinated homomevalonolactone

20 was heated with potassium fluoride in ethyleneglycol to give fluorinated compound 21 in 58\% yield. Ozonolysis of 21 followed by reduction with sodium borohydride afforded fluorinated trio1 22. Oxidation of 22 with silver carbonate on cerite in refluxing benzene (Fetizon et al., 1969) afforded fluorinated homomevalonolactone 23 in $50 \%$ yield. The NMR spectrum for lactone 23 was consistant with the assigned structure.

\section{Biological activities}

Table 2 shows the effects of 3-halopropanol, 3-fluoropropionic acid and related compounds on development of $M$. domestica larvae. Only 3-fluoropropanol and 3fluoropropionic acid inhibited both pupation and adult emergence in $M$. domestica at a high concentration of $5000 \mathrm{ppm}$. 
Table 2. Effects of 3-halopropanols,3-fluoropropionic acid and analogs on development of M. domestica larvae.

\begin{tabular}{lccc}
\hline Compounds & $\begin{array}{c}\text { Dose } \\
(\mathrm{ppm})\end{array}$ & $\begin{array}{c}\text { Pupation } \\
(\%)\end{array}$ & $\begin{array}{c}\text { Adult } \\
\text { emergence (\%) }\end{array}$ \\
\hline $\mathrm{CH}_{3} \mathrm{CH}_{2} \mathrm{CH}_{2} \mathrm{OH}$ & 1000 & 100 & 58 \\
& 5000 & 98 & 70 \\
$\mathrm{BrCH}_{2} \mathrm{CH}_{2} \mathrm{CH}_{2} \mathrm{OH}$ & 1000 & 96 & 56 \\
& 5000 & 92 & 62 \\
$\mathrm{ClCH}_{2} \mathrm{CH}_{2} \mathrm{CH}_{2} \mathrm{OH}$ & 1000 & 98 & 76 \\
& 5000 & 94 & 54 \\
$\mathrm{FCH}_{2} \mathrm{CH}_{2} \mathrm{CH}_{2} \mathrm{OH}$ & 1000 & 96 & 80 \\
$\mathrm{CH}_{3} \mathrm{CH}_{2} \mathrm{COOH}$ & 5000 & 38 & 7 \\
& 1000 & 96 & 60 \\
$\mathrm{FCH}_{2} \mathrm{CH}_{2} \mathrm{COOH}$ & 5000 & 80 & 66 \\
& 1000 & 92 & 80 \\
$\mathrm{Control}$ & 5000 & 32 & 16 \\
\hline
\end{tabular}

Table 3. Insecticidal activities of 3-fluoropropionates.

\begin{tabular}{|c|c|c|c|c|c|c|}
\hline \multirow{3}{*}{$\begin{array}{c}\text { Compounds } \\
\text { No }\end{array}$} & \multirow{3}{*}{$\begin{array}{c}\text { Dose } \\
\& \mathrm{~g} / \text { insect })\end{array}$} & \multicolumn{5}{|c|}{ Mortality (\%) } \\
\hline & & \multicolumn{2}{|c|}{$\begin{array}{l}\text { Silkworm } \\
\text { (3rd instar) }\end{array}$} & & \multicolumn{2}{|c|}{$\begin{array}{l}\text { Housefly } \\
\text { (adults) }\end{array}$} \\
\hline & & 100 & 10 & & 100 & 10 \\
\hline 3 & & 0 & & & 20 & 0 \\
\hline 4 & & 0 & & & 85 & 15 \\
\hline 5 & & 0 & & & 90 & 10 \\
\hline 6 & & 0 & & & 100 & 0 \\
\hline 7 & & 100 & 0 & & 90 & 0 \\
\hline 8 & & 70 & 0 & & 80 & 0 \\
\hline 9 & & 100 & 0 & & 100 & 5 \\
\hline 10 & & 0 & & & 50 & 5 \\
\hline 11 & & 100 & 0 & . & 100 & 0 \\
\hline 12 & & 70 & 10 & & 100 & 5 \\
\hline 13 & & 90 & 0 & & 15 & 0 \\
\hline 14 & & 0 & & & 47 & 15 \\
\hline
\end{tabular}

Single topical appication

The data for the insecticidal activity of 3-fluoropropionates on $B$. mori and $M$. domestica are given in Table 3. None of the compounds showed anti JH activity when applied to 3rd instar larvae of B. mori. For B. mori the octyl 7, dodecyl 9 and geranyl 11 esters showed $100 \%$ mortality at a high dose of $100 \mu \mathrm{g}$ and the toxicity in this series decreased rapidly with decreasing size of the alcohol moiety (compounds 3, 5 and 6). The 3-fluoropropionates showing insecticidal activity on $B$. mori were also active to 
Table 4. Effects of fluorinated compounds on 3rd instar larvae of B.mori (daily topical application).

\begin{tabular}{cccc}
\hline $\begin{array}{c}\text { Compounds } \\
\text { No. }\end{array}$ & $\begin{array}{c}\text { Dose } \\
(\mu \mathrm{g} / \text { larva })\end{array}$ & $\begin{array}{c}\text { Mortality } \\
(\%)\end{array}$ & $\begin{array}{c}\text { Abnormal } \\
\text { pupation }(\%)\end{array}$ \\
\hline 16 & 100 & 100 & \\
17 & 100 & 100 & 40 \\
18 & 10 & 100 & - \\
19 & 100 & 100 & 0 \\
21 & 100 & 0 & 0 \\
22 & 100 & 0 & 60 \\
23 & 100 & 0 & 0 \\
\hline
\end{tabular}

Table 5. Effects of 3-fluoropropionates and related compounds treated in feeding assay on growth of 2 nd instar larvae of $B$. mori.

\begin{tabular}{|c|c|c|c|}
\hline \multirow{2}{*}{$\begin{array}{c}\text { Compounds } \\
\text { No. }\end{array}$} & \multicolumn{3}{|c|}{ Mortality (\%) } \\
\hline & Conc. (ppm) & 1000 & 100 \\
\hline 1 & & 11 & 0 \\
\hline 4 & & 100 & 10 \\
\hline 10 & & 0 & 0 \\
\hline 12 & & 100 & 30 \\
\hline 15 & & 0 & \\
\hline 22 & & 0 & \\
\hline 23 & & 0 & \\
\hline
\end{tabular}

the housefly. The fact that decyl propionate and dodecyl propionate had no insecticidal activity on the housefly at $100 \mu \mathrm{g}$ suggested that the fluorine substituent was significantly affecting the toxicity in this series of compounds. The lower alkyl ester 4,5 and 6 which were quite inactive on the silkworm showed moderate activity on the housefly. The oleyl ester 10 showed comparatively low activity. The benzyl ester 12 had some activity on both insects, but m-phenoxybenzyl ester 14 showed lower activity.

In Table 4 there are presented bioassay data for 3-fluoropropyl ethers, fluorinated homomevalonolactone and related compounds, which were applied to the larvae of $B$. mori at 24-hour intervals during the 3rd instar stage. All of these compounds also failed to elicit anti $\mathrm{JH}$ effects. The ethers 16, 17, 18 and 19 showed $100 \%$ mortality at $100 / * \mathrm{~g} /$ larva. The diene 21 and the diol 22 were quite inactive. It was hoped that fluorinated homomevalonolactone 23, in anlogy with FMev, might inhibit phosphorylation of homomevalonic acid in the $\mathrm{JH}$ biosynthetic pathway, because homomevalonic acid is a precursor of $\mathrm{JH} 0, \mathrm{JH} \mathrm{I}, \mathrm{JH}$ II or iso- $\mathrm{JH} 0$; however no anti $\mathrm{JH}$ activity was found for compound 23. Lactone 23 showed no toxicity in larval B. mori even at 100 $\mu \mathrm{g} /$ larva, but delayed toxicity such as inhibition of pupation. The lack of anti JH activity for lactone 23 was particularly noteworthy.

The effects of several fluorinated compounds were investigated in a feeding 
bioassays (Table 5). When the diets containing each compound were given during 2nd instar stage, 3-fluoropropyl-3-fluoropropionate 4 and the benzyl ester 12 showed $100 \%$ mortality at $1000 \mathrm{ppm}$, but low activity at $100 \mathrm{ppm}$. The lactone 23 and other compounds were quite non-toxic at $1000 \mathrm{ppm}$. None of the compounds showed any anti $\mathrm{JH}$ activity.

\section{REFERENCES}

Czernecki, S., C. Georgoulis et C. Provelenghiou 1976 Nouvelle methode de benzylation d'hydroxyles glucidiques encombres. Tetrahedron Lett., 3535-3536

Fetizon, M., M. Golfier and J. -M. Louis 1969 A new synthesis of lactones: application to ( \pm ). mevalonolactone. J.Chem. Soc. Ckem. Commun., 1118 1119

Pattison, F. L. M., W. C. Howell, A. J. Mcnamara, J. C. Schneider and J. F. Walker 1956 Toxic fluorine compounds III. $\omega$-Fluoroalcohols. J. Org. Chem., 21: 739-747

Prestwich, G. D. 1986 Fluorinated sterols, hormones and pheromones : Enzyme-targeted disruptants in insects. Pestic. Sci., $37: 430-440$

Quistad, G. B., D. C. Cerf, D.A. Schooley and G. B. Staal 1981 Fluoromevalonate acts as an inhibitor of insect juvenile hormone biosynthesis. Nature, $289: 176-177$

Schooley, D.A. and F. C. Baker 1985 Juvenile hormone biosynthesis. In "Comprehensive Insect Physiology, Biochemistry and Pharmacology”, vol. 7, ed. by G. A. Kerkut and L. I. Gilbert, Pergamon Press, Oxford, pp. 363-389

Wigglesworth, V. B. 1985 Historical perspectives. In "Comprehensive Insect Physiology, Biochemistry and Pharmacology", vol. 7, edited by G. A. Kerkut and L. I. Gilbert, Pergamon Press, Oxford, pp. 1-24 